\title{
Prevalence of anxious and depressive symptoms in college students of a public institution
}

\author{
Prevalência de sintomas ansiosos e depressivos em universitários de uma instituição pública \\ Prevalencia de síntomas ansiosos y depresivos en universitarios de una institución pública
}

\section{Márcia Astrês Fernandes', Francisca Emanuelle Rocha Vieira', Joyce Soares e Silva', Fernanda Valéria Silva Dantas Avelino', José Diego Marques Santos'}

'Universidade Federal do Piauí. Teresina, Piauí, Brazil.

\begin{abstract}
How to cite this article:
Fernandes MA, Vieira FER, Silva JS, Avelino FVSD, Santos JDM. Prevalence of anxious and depressive symptoms in college students of a public institution. Rev Bras Enferm [Internet]. 2018;71(Suppl 5):2169-75.

[Thematic Issue: Mental health] DOI: http://dx.doi.org/10.1590/0034-7167-2017-0752
\end{abstract}

\begin{abstract}
Objective: Identify the prevalence of anxious and depressive symptoms and their correlations with sociodemographic and occupational characteristics in university students. Method: This is census, cross-sectional and analytical study, developed with nursing students of a federal public university in the Northeast of Brazil in the months of September and October 2016. 205 university students of all the periods of the course attended the study. Beck's inventories for anxiety and depression were applied. Results: Most of the participants were female, single, native of the state capital and living with his parents. The prevalence of depression was $30.2 \%$ and of anxiety, $62.9 \%$. Association between the level of depressive symptoms, work, sex and leisure was identified. Conclusion: The prevalence of symptoms of anxiety and depression was quite expressive, lacking, thus, more attention to the promotion of mental health of nursing students.
\end{abstract}

Descriptors: Anxiety; Depression; Mental Disorders; Students, Nursing; Schools, Nursing.

\section{RESUMO}

Objetivo: Identificar a prevalência de sintomas ansiosos e depressivos e suas correlações com características sociodemográficas e ocupacionais em universitários. Método: Trata-se de estudo censitário, transversal, e analítico, desenvolvido com estudantes de enfermagem de uma universidade pública federal do Nordeste do Brasil nos meses de setembro e outubro de 2016. Participaram 205 universitários de todos os períodos do curso. Foram aplicados os inventários de Beck para ansiedade e depressão. Resultados: A maioria dos participantes era do sexo feminino, solteira, natural da capital do estado e morava com os pais. A prevalência de depressão foi de 30,2\% e de ansiedade, 62,9\%. Identificou-se associação entre o nível de sintomas depressivos, trabalho, sexo e lazer. Conclusão: A prevalência dos sintomas de ansiedade e depressão foi bastante expressiva, carecendo, portanto, de mais atenção e promoção à saúde mental dos estudantes de enfermagem.

Descritores: Ansiedade; Depressão; Transtornos Mentais; Estudantes de Enfermagem; Escolas de Enfermagem.

\section{RESUMEN}

Objetivo: Identificar la prevalencia de síntomas ansiosos y depresivos y sus correlaciones con características sociodemográficas y ocupacionales en universitarios. Método: Se trata de un estudio censal, transversal, y analítico, desarrollado con estudiantes de enfermería de una universidad pública federal del Nordeste de Brasil en los meses de septiembre y octubre de 2016. Participaron 205 universitarios de todos los períodos del curso. Se aplicaron los inventarios de Beck para la ansiedad y la depresión. Resultados: La mayoría de los participantes era del género femenino, soltera, natural de la capital del estado y vivía con los padres. La prevalencia de depresión fue del 30,2\%, y de ansiedad el 62,9\%. Se identificó asociación entre el nivel de síntomas depresivos, trabajo, sexo y ocio. Conclusión: La prevalencia de los síntomas de ansiedad y depresión fue bastante expresiva, necesitando, por lo tanto, de más atención y promoción a la salud mental de los estudiantes de enfermería.

Descriptores: Ansiedad; Depresión; Trastornos Mentales; Estudiantes de Enfermería; Facultades de Enfermería. 


\section{INTRODUCTION}

The university brings big changes for students' life. The pace of life becomes more intense, the workload of studies is increased, and often the geographical distance of the family, as well as the imposition of charges by the society, by the institution and by the student himself may provoke feelings such as disappointment, irritability, anxiety and impatience during graduation ${ }^{(1-2)}$.

Such situations are, in many cases, anxiety factors and possible triggers for depression. High prevalence of depression in university students is observed, on average $30.6 \%$, while for the population in general, this prevalence corresponds to $9 \%$. Some studies indicate a prevalence of anxiety in college students varying between $63 \%$ and $92 \%{ }^{(2-3)}$.

Considered a public health issue, depression is a multifactorial disease that interfere with the interpersonal, social and professional functioning of the individual. It consists of mood changes, loss of initiative, general lack of interest, sleep disorders, lack of self-care, decreased ability to concentrate, anxiety, among other symptoms ${ }^{(2)}$.

Among the risk factors most associated with depression, family history, personality-related aspects, as well as unpleasant experiences in the daily lives of the person may be highlighted. Studies show mental disorders, particularly depression, are among the strongest risk factors for suicide attempt $\mathrm{t}^{(1,4)}$.

Anxiety, also considered a common mental disorder, consists of a physiological response of human beings to the environment into which they are inserted and the situations they experience; however, it can become pathological, characterizing by distress, difficulty in concentrating, sleep disorders, fatigue, trembling, among others ${ }^{(5)}$.

When compared with other university students, nursing students have additional factors that may cause anxiety: the clinical practice experience, the relationship with the patient, the distress and the fear of making mistakes are singled out as key factors triggering anxiety, in addition to situations in which they must deal with the imminence of death. Besides facing a heavy academic overload and an increasingly competitive environment, they must strive for academic excellence to meet the demands from the labor market ${ }^{(6-8)}$.

The common mental disorders in this population are emerging problems and its prevalence is a concerning factor, as well as its deleterious effects on the students' health. Moreover, suicide cases in this population group draws attention for their upward trends ${ }^{(9)}$. Given the magnitude of this problem, knowing the prevalence of anxious and depressive symptoms in students is relevant to develop prevention plans and other mechanisms for strengthening the mental health of these university students.

\section{OBJECTIVE}

Identify the prevalence of anxious and depressive symptoms and their correlations with sociodemographic and occupational characteristics in university students.

\section{METHOD}

\section{Ethical aspects}

This research was approved by the Research Ethics Committee of the Federal University of Piauí on August, 5, 2016. All the participants signed the informed consent form. At all stages of the study, the ethical principles of the Resolution 466/2012 by the Brazilian National Health Council, which reports on the ethical and legal issues of research involving human beings, were followed.

\section{Study design, site and period}

This is a cross-sectional and analytical census study, developed with nursing students of a public federal university in the Northeast of Brazil, in September and October 2016. The initial population was composed of 281 university students, 205 of whom participated in the survey - the others did not accept to participate or did not meet the inclusion criteria, representing a loss of $27 \%$ of the study population.

\section{Sample, inclusion and exclusion criteria}

The students who were regularly enrolled in the course during the collection period, were 18 or more years old and attended the course met the criteria for inclusion. The students who were not attending the course due to medical leave, international student mobility programs or who suspended their enrollment were excluded.

\section{Study protocol}

The data collection instruments used were sociodemographic and occupational questionnaire, Beck Anxiety Inventory (BAI) and Beck Depression Inventory (BDI). BAI consists of 21 questions, each one has four answer possibilities related to how the individual has felt last week, expressed by common anxiety symptoms. The maximum result is 63 points, and the categories are: $0-7$, minimum anxiety; $8-15$, mild anxiety; $16-25$, moderate anxiety; 26-63, severe anxiety ${ }^{(6)}$.

$\mathrm{BDI}$ is composed of 21 items that include symptoms and are classified into four levels of intensity. Each item has four answers $(0,1,2$ or 3$)$, being possible to have more than one answer in each question, but only the one with higher value is validated. The total scores can range from 0 to 63 , suggesting the following severity level: 0-13, minimum/no depression; 14-19, mild depression; 20-28, moderate depression; and 29-63, severe depression. Both instruments have been translated and validated in Brazil ${ }^{(6,10)}$.

Considering that these scales are restricted to the psychology field, a psychologist evaluated these instruments.

In this study, cut-off points for analysis of the information obtained were determined. The cut-off point to classify the patients should consider the sample characteristics, once Statistics proposes using the median reference. Thus, the literature mentions better classification between patients who are "dysthymic" and "not depressed" in the cut-off point 23. The cutoff 18 could provide an estimate of "possible depression" and the cutoff 8 identifies the highest and lowest level of depressive symptoms $\mathrm{s}^{(11)}$.

For anxiety, three cut-off points were also used: 21 cutoff for diagnosis of anxiety or not; 18 cutoff for possible problem and 11 cutoff for measuring the existence of anxiety symptoms ${ }^{(12)}$.

\section{Analysis of the results and statistics}

Software IBM ${ }^{\circledR}$ SPSS $^{\circledR}$, version 18.0, processed the data. Descriptive statistics were calculated as averages, standard deviation, minimum and maximum. For dichotomization of the quantitative 
variables, the measure of distributions was used. The Pearson's chi-square test was performed to verify associations between the characteristics of nursing students and the classifications regarding the level of depressive and anxiety symptoms in different cutoffs. When the purposes of this test were not fulfilled, Fisher's exact test was performed. For the significant associations, the prevalence ratio and its confidence interval were calculated. For all the analyses, the significance level was $5 \%$.

\section{RESULTS}

The sample showed an average age of $21.8( \pm 3.8)$ years, from 18 (minimum) to 50 (maximum) years old. The majority was female $(81.5 \%)$, single $(91.6 \%)$, born in the capital of the state $(70.2 \%)$ and living with parents $(73.0 \%), 15$ of them had children, with maximum of $2(1.1 \pm 0.3)$.

Among the college students, $52.7 \%$ attended the course until the second year, and $47.3 \%$, from the third year on. $63.9 \%$ developed extracurricular activities, including extension course $(23.9 \%)$, academic tutoring (10.2\%), scientific initiation (7.8\%) and internship (5.9\%), with an average duration of $12.9( \pm 8.3)$ and a maximum of 40 hours per week. Among those who had a work or were employed (13.2\%), the average workload per week was $18.6( \pm 13.9)$, with a minimum of 2 and maximum of 40 hours.

Considering the overall score, the average obtained by the university students was $10.1( \pm 7.7)$ points, with a minimum of 0 and a maximum of 42 , for the level of depression symptoms. Most of them showed minimum value or absence $(143,69.8 \%)$ of these symptoms, 40 (19.5\%) had mild depression and 14 , moderate depression $(6.8 \%)$. The average level of anxiety symptoms in students was $13.2( \pm 10.0)$, with a minimum of 0 and a maximum of 49 points. Comparing the level of depressive symptoms, the levels of anxiety symptoms were higher: mild $(62,30.2 \%)$, moderate (44, $21.5 \%)$ and severe $(23,11.2 \%)$ (Figure 1 ).

The most frequent depressive symptoms in the mild levels were: fatigue $(106,56.4 \%)$, irritability $(102,49.8 \%)$, somatic concerns (94 $49.7 \%)$, and sleep disorders $(87,46 \%), 41(20 \%)$ reported indecision in moderate level and 15 (7.3\%) showed irritability in severe level.

The distribution of the students according to level of depressive symptoms has increased as the value of the cut-off point for classification was reduced. Among the students, 11 (5.4\%) had depression (cutoff 23), 35 (17.1\%) showed possible depression (cutoff 18) and $104(50.7 \%)$ presented a higher level of depressive symptoms in the sample, with scores greater than or equal to 8 (Figure 2).

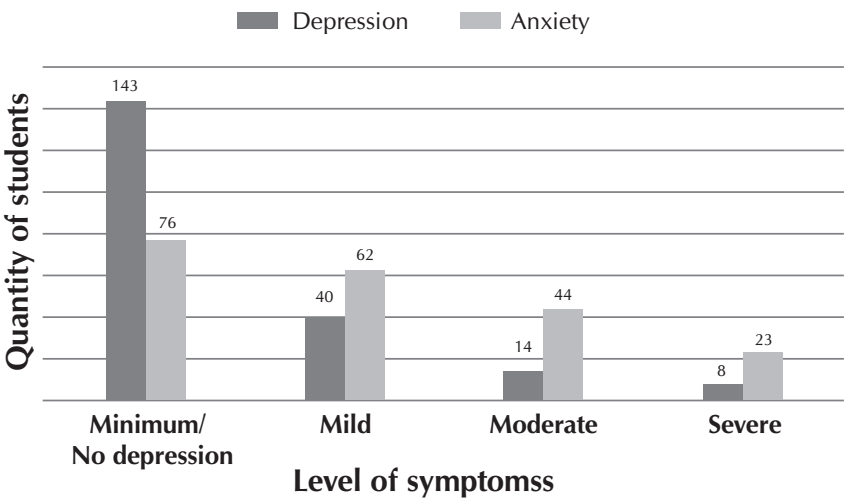

Figure 1 - Classification of university students regarding the presence of depression and anxiety symptoms. Teresina, Piauí, Brazil, $2016(\mathrm{~N}=205)$

Table 1 - Students' response levels for the Beck Depression Inventory, Teresina, Piauí, Brazil, 2016 (N = 205$)$

\begin{tabular}{|c|c|c|c|c|c|c|c|c|}
\hline \multirow{2}{*}{ Item } & \multicolumn{2}{|c|}{ Level 0} & \multicolumn{2}{|c|}{ Level 1} & \multicolumn{2}{|c|}{ Level 2} & \multicolumn{2}{|c|}{ Level 3} \\
\hline & $\mathbf{n}$ & $\%$ & $\mathbf{n}$ & $\%$ & $\mathbf{n}$ & $\%$ & $\mathbf{n}$ & $\%$ \\
\hline Sadness & 111 & 54.1 & 84 & 41.0 & 7 & 3.4 & 3 & 1.5 \\
\hline Pessimism & 141 & 68.8 & 57 & 27.8 & 2 & 1.0 & 5 & 2.4 \\
\hline Feeling of failure & 151 & 73.7 & 45 & 22.0 & 5 & 2.4 & 4 & 2.0 \\
\hline Absence of satisfaction* & 115 & 56.4 & 79 & 38.7 & 5 & 2.5 & 5 & 2.5 \\
\hline Guilt** & 140 & 69.0 & 48 & 23.6 & 13 & 6.4 & 2 & 1.0 \\
\hline Feeling of punishment & 141 & 68.8 & 57 & 27.8 & 2 & 1.0 & 5 & 2.4 \\
\hline Self-hatred & 151 & 73.7 & 45 & 22.0 & 5 & 2.4 & 4 & 2.0 \\
\hline Self-accusation & 115 & 56.1 & 79 & 38.5 & 5 & 2.4 & 5 & 2.4 \\
\hline Suicidal thoughts & 174 & 84.9 & 28 & 13.7 & 2 & 1.0 & 1 & 0.5 \\
\hline Bouts of crying & 138 & 67.3 & 50 & 24.4 & 9 & 4.4 & 8 & 3.9 \\
\hline Irritability & 78 & 38.0 & 102 & 49.8 & 10 & 4.9 & 15 & 7.3 \\
\hline Social retraction & 115 & 56.1 & 79 & 38.5 & 10 & 4.9 & 1 & 0.5 \\
\hline Indecision & 88 & 42.9 & 74 & 36.1 & 41 & 20.0 & 2 & 1.0 \\
\hline Distortion of the body self-image $* * * *$ & 123 & 65.4 & 39 & 20.7 & 7 & 3.7 & 19 & 10.1 \\
\hline Decrease in productivity at work & 114 & 60.6 & 57 & 30.3 & 15 & 8.0 & 2 & 1.1 \\
\hline Sleep disorders $* * *$ & 87 & 46.0 & 87 & 46.0 & 12 & 6.3 & 3 & 1.6 \\
\hline Fatigue $* * * *$ & 53 & 28.2 & 106 & 56.4 & 19 & 10.1 & 10 & 5.3 \\
\hline Appetite alterations $* * *$ & 142 & 75.1 & 35 & 18.5 & 10 & 5.3 & 2 & 1.1 \\
\hline Changes in body weight*** & 168 & 88.9 & 19 & 10.1 & 2 & 1.1 & - & - \\
\hline Somatic concern $* * *$ & 88 & 46.6 & 94 & 49.7 & 7 & 3.7 & - & - \\
\hline Decreased libido** & 153 & 81.4 & 29 & 15.4 & 5 & 2.7 & 1 & 0.5 \\
\hline
\end{tabular}

Note: ${ }^{*} n=204 ; * * n=203 ; n=189 ; * * * * n=188$ 
Table 2 - Students's response levels for the Beck Anxiety Inventory, Teresina, Piauí, Brazil, 2016 (N = 205)

\begin{tabular}{|c|c|c|c|c|c|c|c|c|}
\hline \multirow{2}{*}{ Item } & \multicolumn{2}{|c|}{ Level 0} & \multicolumn{2}{|c|}{ Level 1} & \multicolumn{2}{|c|}{ Level 2} & \multicolumn{2}{|c|}{ Level 3} \\
\hline & $\mathbf{n}$ & $\%$ & $\mathbf{n}$ & $\%$ & $\mathbf{n}$ & $\%$ & $\mathbf{n}$ & $\%$ \\
\hline Numbness or tingling & 124 & 60.5 & 60 & 29.3 & 19 & 9.3 & 1 & 0.5 \\
\hline Feeling of warmth & 63 & 30.7 & 58 & 28.3 & 61 & 29.8 & 23 & 11.2 \\
\hline Trembling in the legs & 139 & 67.8 & 47 & 22.9 & 16 & 7.8 & 3 & 1.5 \\
\hline Inability to relax & 86 & 42.0 & 61 & 29.8 & 46 & 22.4 & 12 & 5.9 \\
\hline Fear of the worst happening & 64 & 31.2 & 60 & 29.3 & 59 & 28.8 & 20 & 9.8 \\
\hline Dazedness or dizziness & 127 & 62.0 & 49 & 23.9 & 23 & 11.2 & 5 & 2.4 \\
\hline Palpitation/acceleration in the heart & 104 & 50.7 & 59 & 28.8 & 33 & 16.1 & 9 & 4.4 \\
\hline Unbalance & 152 & 74.1 & 39 & 19.0 & 11 & 5.4 & 3 & 1.5 \\
\hline Terror & 151 & 73.7 & 31 & 15.1 & 14 & 6.8 & 9 & 4.4 \\
\hline Nervousness & 41 & 20.0 & 80 & 39.0 & 60 & 29.3 & 23 & 11.2 \\
\hline Feeling of suffocation & 142 & 69.3 & 38 & 18.5 & 18 & 8.8 & 7 & 3.4 \\
\hline Trembling in the hands & 140 & 68.3 & 41 & 20.0 & 15 & 7.3 & 9 & 4.4 \\
\hline Tremor & 142 & 69.3 & 43 & 21.0 & 15 & 7.3 & 5 & 2.4 \\
\hline Fear of losing control & 112 & 54.6 & 63 & 30.7 & 23 & 11.2 & 6 & 2.9 \\
\hline Difficulty in breathing & 145 & 70.7 & 43 & 21.0 & 14 & 6.8 & 3 & 1.5 \\
\hline Fear of dying & 118 & 57.6 & 56 & 27.3 & 24 & 11.7 & 6 & 2.9 \\
\hline Scare & 96 & 46.8 & 73 & 35.6 & 28 & 13.7 & 8 & 3.9 \\
\hline Indigestion/discomfort in the abdomen & 80 & 39.0 & 73 & 35.6 & 42 & 20.5 & 10 & 4.9 \\
\hline Feeling of faint & 166 & 81.0 & 28 & 13.7 & 9 & 4.4 & 2 & 1.0 \\
\hline Flushed face & 163 & 79.5 & 27 & 13.2 & 11 & 5.4 & 3 & 1.5 \\
\hline Sweat (nonthermal) & 134 & 65.4 & 49 & 23.9 & 16 & 7.8 & 6 & 2.9 \\
\hline
\end{tabular}

The most evident anxiety symptoms were: nervousness (80, $39.2 \%)$, feeling of being scared $(73,35.6 \%)$ and indigestion or abdominal discomfort $(73,35.6 \%)$, all of them in mild levels, whereas for the moderate level nervousness $(60,29.4 \%)$ and fear of the worst happening $(59,29.1 \%)$ were more frequent.

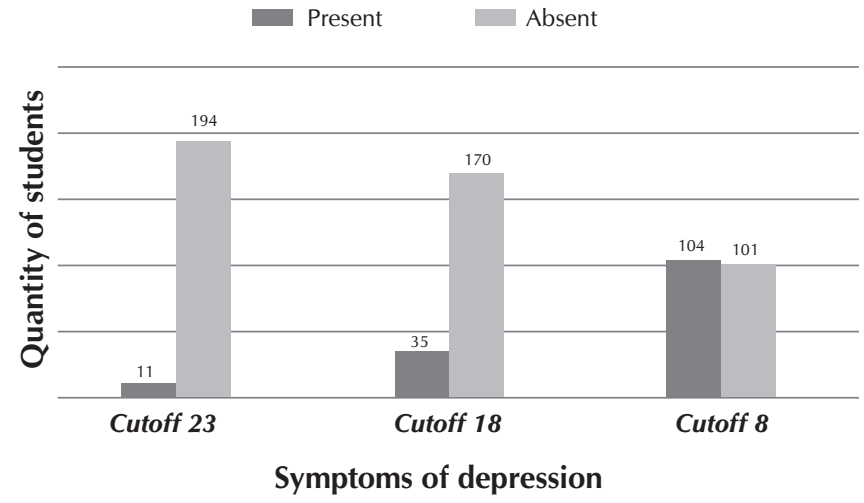

Figure 2 - Distribution in cutoffs of the evaluation regarding the presence of depression symptoms in university students. Teresina, Piauí, Brazil, 2016 ( $N=205)$

The distribution of the university students regarding their level of anxiety symptoms varied according to the cutting point. Among them, 43 (21.0\%) had anxiety (cutoff 21), 150 (73.2\%) showed possible anxiety (cutoff 18) and 105 (51.2\%) showed higher level of anxious symptoms in the sample of students, with scores greater than or equal to 11 (Figure 3).

Association between the level of depressive symptoms and work or job activities $(\mathrm{p}=0.042)$ and hours for leisure $\left(\mathrm{x}^{2}\right.$ $=7.681 ; p=0.006)$ and $\operatorname{sex}\left(x^{2}=5.094 ; p=0.024\right)$ was identified. Nursing students who worked had a prevalence of depression 3.75 (CI95\% = 1.17-11.9) times higher (cutoff 23); those who had up to 14 hours of leisure per week showed a prevalence of possible depression $2.79(\mathrm{Cl} 95 \%=1.27-6.12)$ times higher (cutoff 18); and female university students had $59 \%$ higher prevalence $(\mathrm{Cl} 95 \%=1.01-2.53)$ of the more severe level of depressive symptoms (cutoff 8 ) in the sample.

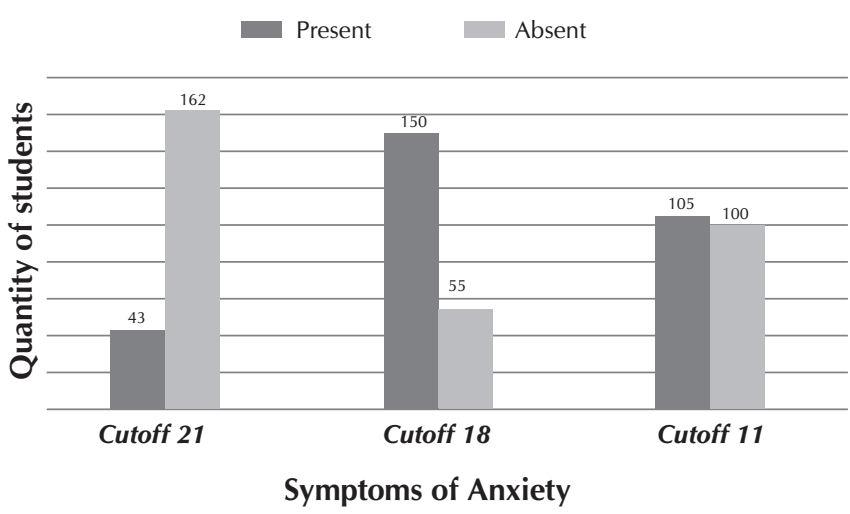

Figure 3 - Distribution in cutoffs of the evaluation regarding the presence of anxiety symptoms in university students, Teresina, Piauí, Brazil, 2016 ( $N=205)$

\section{DISCUSSION}

Most of the students of the study was single and female. The women's percentage in the nursing course, according to the literature, is between $55.3 \%$ and $93.4 \%$ in several countries - this can be explained by the fact that nursing is a profession historically 
practiced by women ${ }^{(5,13-14)}$. The relationship between nursing, gender and care is pretty remote, but should not be regarded as primitive. Nursing is still largely practiced by the female gender, but the number of men in the profession is increasing.

The average prevalence of depression in college students is $30.6 \%$, whereas in the nonuniversity population is $9 \%{ }^{(2)}$. The prevalence found in this study was $30.2 \%$. Thus, it may be realized that the participants of this survey showed a percentage rate next to the expected values for the university population. When compared with the nonuniversity population, the students of the study showed percentages about three times higher, which may de related to the lifestyle, competitive environment, demands for better performances, among other factors.

In a recent study conducted with nursing students in an education institution in Brasília, DF, the prevalence of depressive symptoms identified was $62.6 \%$ for minimum, $25.2 \%$ for mild, $10.9 \%$ for moderate and $1.1 \%$ for severe ${ }^{(14)}$. Although the statistics for severe depressive symptoms, noticeably, are not the majority, the percentages for moderate/mild symptoms is a concern when considering that the risk of developing mood disorders, particularly depression, increases with age. Therefore, the values for mild and moderate symptoms may be the first manifestations of the disease, which can worsen ${ }^{(15)}$.

The symptoms addressed in the BDI were identified in different severity levels, and the fatigue was reported to a considerable number of participants. It is believed that nursing students are more exposed to fatigue in the period of the course in which the clinical practices become more intense, and when they become nurses, they are more vulnerable in the beginning of their careers, with the following triggers: the nature of the work, the lack of social and administrative support, the workload/change and specific demands ${ }^{(16)}$.

Moreover, more than half of the participants self-reported sleep disorders. A cross-sectional study performed in Turkey investigated insomnia, anxiety and depression in 379 nursing students, identifying that the higher were the levels of anxiety and depression in the participants, the greater was the insomnia severity. In addition, students who were smokers and with a lower income and a irregular sleep schedule had a greater risk of having insomnia, corroborating the results found in this study ${ }^{(17)}$.

The literature is controversial regarding the correlation of depressive symptoms with the period of the course in which the students are. A survey conducted in India points out that the depressive symptoms are more intense during the first year of the course, decreasing gradually from this period on ${ }^{(1)}$. However, cross-sectional studies carried out in Malaysia and China and a exploratory-descriptive study conducted in Brazil corroborate these findings when revealing that these symptoms are more severe in the last periods of the course ${ }^{(3,14,18)}$. Such a divergence in the literature can be explained by cultural, social and economic differences between these countries and by the way the course is structured, its curriculum and workload, for example, are factors that vary according to the university and society in question.

Women had a higher prevalence of depressive symptoms, corroborating the literature, in which the prevalence of depression in women is twice the prevalence in men. A possible explanation may be related to cultural factors. Firstly, depressive symptoms (sadness, crying) are at odds with the social ideals of masculinity, i.e., men may be reluctant to report these symptoms. Secondly, the male experiences of depression may manifest through symptoms not currently included in the traditional diagnostic criteria, such as anger, self-destructive behavior, self-distraction, use of psychoactive substances, gambling and work addiction, and sexual intercourses with multiple partners ${ }^{(19)}$.

The level of depressive symptoms was associated with activities of work or job - this may be related to stress, whether physical or mental, which is used in the performance of the daily work activities. A survey conducted in São Paulo, Brazil, recognizes the existence of difficulties in making adjustments between the education requirements and the need to work. The fact that the student is also a worker appears as a complicating factor when it comes to finishing college. Thus, conciliating work and college degree is something that requires great struggle from the student, which can lead to the emergence of characteristic symptoms of depression, affecting his/her quality of life and decreasing both his/her academic and professional performance ${ }^{(13,20)}$.

Little time for leisure was also associated with the level of depressive symptoms, reaffirming what has been observed in a Hong Kong study, in which the lack of entertainment and leisure have been associated with depression among nursing college students ${ }^{(13)}$.

Moreover, a study conducted at the School of Medical Sciences of the State University of Campinas, SP, with participants from several courses of the medical area, identified that the lack of free time for leisure, relationships and home is one of the main factors that influence negatively on the quality of life of university students ${ }^{(21)}$. Little time for leisure activities and low quality of these activities can be related to high demands of the course and the performance of many extracurricular activities simultaneously, which are nothing but results of a competitive labor market ${ }^{(22)}$.

In relation to the anxiety symptoms, using the Beck Anxiety inventory, this study demonstrated that $62.9 \%$ of nursing college students have these symptoms, similarly to the prevalence of $70 \%$ revealed in nursing students of a public institution in a study in the city of São Paulo, SP(6).

The literature points out that mild anxiety levels can boost the performance of students, but it causes performance decrease at higher levels ${ }^{(6)}$. Therefore, the higher the anxiety level, the greater the damage to the individual regarding his/her cognitive aspects, such as attention, memory, concentration and reasoning, thus decreasing the overall performance. Even though many variables contribute to the emergence of anxiety symptoms, the most common factors involve the academic performance, social stressors, financial problems and adjustments inherent to the transition from family to university environment ${ }^{(5)}$.

In Colombia, the anxiety was correlated to economic difficulties and family problems, whereas a study conducted in Brazil identified the associations with the female gender and the lack of leisure activity ${ }^{(5,21-22)}$. However, no statistically significant associations were observed between the classifications of nursing students regarding their anxiety levels, in the distinct cut-off points, and their sociodemographic and occupational characteristics.

\section{Limitation of the study}

This study is limited because of its conduction in a population of only one course, for, given the importance of the issue 
in the academic field, it is important that the investigation can be expanded to other medical courses.

\section{Contributions to the nursing field}

The existence of anxious and depressive symptoms in the university population, especially in nursing students, is a problematic of unquestionable relevance in the medical field, given that the academic environment is permeated by stressor situations that can influence the appearance of anxiety and depression. Therefore, investigation is required to subsidize the implementation of mental health intervention actions for the student community.

\section{CONCLUSION}

The prevalence of anxiety and depression symptoms was quite expressive; $62.9 \%$ and $30.2 \%$, respectively, occurring mainly in mild levels. The sociodemographic and occupational analysis revealed that females are more prone to develop depressive symptoms and that factors such as work and leisure are also related to depression. In relation to the reported symptoms, nervousness, feeling of being scared, indigestion or abdominal discomfort, fear of the worst to happen, fatigue and irritability were the most evident.

\section{REFERENCES}

1. Chatterjee S, Saha I, Mukhopadhyay S, Misra R, Chakraborty A, Bhattacharya A. Depression among nursing students in a Indian government college. Br J Nurs[Internet]. 2014[cited 2017 Sep 11];23(6):316-20. Available from: https://www.magonlinelibrary. com/doi/10.12968/bjon.2014.23.6.316

2. Ibrahim AK, Kelly SJ, Adams CE, Glazebrook C. A systematic review of studies of depression prevalence in university students. J Psychiatr Res[Internet]. 2013[cited 2017 Sep 11];47(3):391-400. Available from: https://www.journalofpsychiatricresearch.com/ article/S0022-3956(12)00357-3/fulltext

3. Shamsuddin K, Fadzil F, Ismail WSW, Shah SA, Omar K, Muhammad NA, et al. Correlates of depression, anxiety and stress among Malaysian university students. Asian J Psychiatr[Internet]. 2013[cited 2017 Sep 11];6(4):318-23. Available from: https://www. asianjournalofpsychiatry.com/article/S1876-2018(13)00059-2/fulltext

4. Herrero AA, Sábado JT, Benito JG. Associations between emotional intelligence, depression and suicide risk in nursing students. Nurse Educ Today[Internet]. 2014[cited 2017 Sep 11];34(4):520-5. Available from: https://www.nurseeducationtoday.com/article/ S0260-6917(13)00239-6/fulltext

5. Chaves ECL, Lunes DH, Moura CC, Carvalho LC, Silva AM, Carvalho EC. Anxiety and spirituality in university students: a crosssectional study. Rev Bras Enferm[Internet]. 2015[cited 2017 Sep 11];68(3):444-9. Available from: http://www.scielo.br/pdf/reben/ v68n3/en_0034-7167-reben-68-03-0504.pdf

6. Marchi KC, Bárbaro AM, Miasso AI, Tirapelli CR. Ansiedade e consumo de ansiolíticos entre estudantes de enfermagem de uma universidade pública. Rev Eletrôn Enferm[Internet]. 2013[cited 2017 Sep 11];15(3):729-37. Available from: https://revistas.ufg.br/ fen/article/view/18924

7. Xu Y, Chi X, Chen S, Qi J, Zhang P, Yang Y. Prevalence and correlates of depression among college nursing students in China. Nurse Educ Today[Internet]. 2014[cited 2017 Sep 11];34(6):e7-12. Available from: https://www.nurseeducationtoday.com/article/ S0260-6917(13)00393-6/fulltext

8. Lamis DA, Ballard ED, May AM, Dvorak RD. Depressive symptoms and suicidal ideation in college students: the mediating and moderating roles of hopelessness, alcohol problems, and social support. J Clin Psychol[Internet]. 2016 [cited 2017 Sep 11];72(9):919-32. Available from: https://onlinelibrary.wiley.com/doi/abs/10.1002/jclp.22295

9. Lima R. Os suicídios e a universidade produtivista. Rev Esp Acad[Internet]. 2013[cited 2017 Dec 26];13(149):78-86. Available from: http://www.periodicos.uem.br/ojs/index.php/EspacoAcademico/article/view/22070/11718

10. Oliveira MHG, Gorenstein C, Lotufo Neto F, Andrade LH, Wang YP. Validation of the Brazilian Portuguese version of the Beck Depression Inventor-II in a community sample. Rev Bras Psiquiatr[Internet]. 2012[cited 2017 Sep 11];34(4):389-94. Available from: http://dx.doi.org/10.1016/j.rbp.2012.03.005

11. Martinsen E, Friss S, Hoffart A. Assessment of depression comparison between Beck Depression Inventory and Subscales of Comprehensive Psychopathological Rating Scale. Acta Psychiatr Scand[Internet]. 1995[cited 2017 Sep 11];92(6):460-3. Available from: https://www.ncbi.nlm.nih.gov/pubmed/8837974

12. Beck AT, Beamesderfer A. Assessment depression: the depression inventory. Mod Probl Pharmacopsychiatry[Internet]. 1974[cited 2017 Sep 11];7(0):151-69. Available from: https://www.ncbi.nlm.nih.gov/pubmed/4412100

13. Cheung T, Wong SY, Wong KY, Law LY, Ng K, Tong MT, et al. Depression, anxiety and symptoms of stress among baccalaureate nursing students in Hong Kong: a cross-sectional study. Int J Environ Res Public Health[Internet]. 2016[cited 2017 Sept 11];13(8):125. Available from: http://www.mdpi.com/1660-4601/13/8/779

14. Camargo RM, Sousa CO, Oliveira MLC. Prevalence of cases of depression in nursing students in an institution of higher education in Brasilia. Rev Min Enferm[Internet]. 2014[cited 2017 Sep 11];18(2):398-403. Available from: http://www.reme.org.br/artigo/ detalhes/935 
15. Telles Filho PCP, Pereira Jr AC. Antidepressivos: consumo, orientação e conhecimento entre os acadêmicos de enfermagem. Rev Enferm Cent-Oeste Min[Internet]. 2013[cited 2017 Sep 11];3(3):829-36. Available from: http://www.seer.ufsj.edu.br/index.php/ recom/article/view/411

16. Jones PB. Adult mental health disorders and their age at onset. BJ Psych Int[Internet]. 2013[cited 2017 Sep 02];202(s54):s5-10. Available from: http://bjp.rcpsych.org/content/202/s54/s5

17. Mihalec B, Diefenbeck C, Mahoney M. The calm before the storm? burnout and compassion fatigue among undergraduate nursing students. Nurse Educ Today[Internet]. 2013[cited 2017 Sep 02];33(4):314-20. Available from: https://www.nurseeducationtoday. com/article/S0260-6917(13)00028-2/fulltext

18. Güneş Z, Arslantaş H. Insomnia in nursing students and related factors: a cross-sectional study. Int J Nurs Pract[Internet]. 2017[cited 2017 Sep 19];e12578. Available from: https://onlinelibrary.wiley.com/doi/abs/10.1111/ijn.12578

19. Souza IMDM, Paro HBMS, Morales RR, Pinto RMC, Silva CHM. Health-related quality of life and depressive symptoms in undergraduate nursing students. Rev Latino-Am Enfermagem[Internet]. 2012[cited 2017 Sep 11];20(4):736-43. Available from: http://www.scielo.br/pdf/rlae/v20n4/14.pdf

20. Martin LA, Neighbors HW, Griffith DM. The experience of symptoms of depression in men vs women: analysis of the National Comorbidity Survey Replication. JAMA Psychiatr[Internet]. 2013[cited 2017 Sep 19];70(10):1100-6. Available from: https:// jamanetwork.com/journals/jamapsychiatry/fullarticle/1733742

21. Vargas HM, Paula MFC. A inclusão do estudante-trabalhador e do trabalhador-estudante na educação superior: desafio público a ser enfrentado. Rev Aval Educ Sup[Internet]. 2013[cited 2017 Sep 11];18(2):459-85. Available from: http://www.scielo.br/pdf/ aval/v18n2/11.pdf

22. Parol CA, Bittencourt ZZLC. Qualidade de vida de graduandos da área da saúde. Rev Bras Educ Med[Internet]. 2013 [cited 2017 Sep 11];37(3):365-75. Available from: http://www.scielo.br/pdf/rbem/v37n3/09.pdf 